\title{
Some characteristics of social interactions among adolescents in Croatia, Bosnia and Herzegovina, and Macedonia
}

\author{
This article was published in the following Dove Press journal: \\ Psychology Research and Behavior Management \\ I4 November 2012 \\ Number of times this article has been viewed
}

\author{
Mira Klarin' \\ Ana Pororoković ${ }^{2}$ \\ Slavica Šimić Šašićl \\ Violeta Arnaudova ${ }^{3}$ \\ 'Department of Teacher and \\ Preschool Teacher Education, \\ University of Zadar, Zadar, Croatia; \\ ${ }^{2}$ Department of Psychology, University \\ of Zadar, Zadar, Croatia; ${ }^{3}$ Faculty of \\ Philosophy, Department of Psychology, \\ University of Ćiril and Method, \\ Skopje, Macedonia
}

Introduction: The bioecological model refers to the basic social needs that a person has satisfied through social interactions. In individualist cultures, the need for independence is emphasized with the aim of self-realization and personal achievement. In collectivist cultures, togetherness is encouraged and it prevails over individuality.

Aim: The aim of this study was to determine whether there were differences in adolescents ( $n=1033$ ) from three different cultural environments (Croatia, Bosnia and Herzegovina, and Macedonia) with regard to the various aspects of the social interactions and behaviors these adolescents exercise with their parents and friends.

Methods: Three groups of questionnaires were used: those that measure family interactions (the quality of family interactions, loneliness in the family, and family influence); those that assess peer interactions (quality of friendships, social loneliness, and influence of friendships); and those that examined behavioral variables (self-esteem, aggression, and prosocialness).

Results: Discriminant analysis has shown that there are two significant functions that differentiate subjects from the three different cultural environments. The first discriminant function that adequately discriminates between subjects in all three cultural environments is related to social and family loneliness and the influence of friends. Loneliness in the family, social loneliness, and influence of friends are most prevalent among adolescents in Macedonia and least among adolescents in Croatia. The second function that distinguished adolescents in Croatia from those in the other two cultural environments was primarily connected with the quality of family interactions, aggressiveness, parent influence, and self-esteem. Finally, it was found that adolescents from Bosnia and Herzegovina were more likely to engage in family interactions, have greater levels of parental influence, and appeared to be less aggressive and had lower self-esteem than adolescents from the other two regions.

Keywords: cultural differences, individualist, collectivist, family interactions, group interactions

\section{Introduction}

In order to generate a more comprehensive understanding of child development, an increased amount of research has been recently conducted in the field of developmental psychology with the aim of studying social interactions within the cultural contexts in which this development occurs. In other words, research of the ecological basis of development is the subject of a growing body of research in developmental psychology. Research at this macrosystem level contributes to a better understanding of the process of socialization. ${ }^{1}$

The ecological perspective of development implies that the effects of a given social environment on development should be investigated. Many authors emphasize the 
importance of peer social interactions, ${ }^{2,3}$ early interactions with the caregiver, ${ }^{4}$ and the importance of the so-called cultural script for the behavior of parents, which is directed to the child and which is based on cultural experience. This cultural script is reflected in parents' parenting strategies. ${ }^{1}$

Cultural contexts play an important role in the development of a person's social and behavioral characteristics. ${ }^{5}$ The findings from previous research have led to the conclusion that differences in cultural belonging result in different forms of social interactions, and thus influence the development of different types of social relationships. In accordance with the system of values, educational goals, conventional forms of interaction, and cultural norms, the child develops his or her own mechanisms of interaction, which are later used in his or her own social relationships.

The ecological perspective of development is especially emphasized in Bronfenbrenner's bioecological theory. ${ }^{6}$ In this model of development, the child has his or her first interactions within his or her immediate surroundings, such as with his or her family (microsystem). Bronfenbrenner's microsystem is defined as:

a set of activities, roles and interpersonal relations a

person experiences in "face-to-face" interactions with specific physical, social and symbolic characteristics of the environment which either facilitate or inhibit its involvement in more complex interactions with the immediate surroundings or acting in them. ${ }^{6}$

Interactions at the "face-to-face" level create the foundations of the so-called internal working model, which the child uses during interactions with other people within the microsystem (eg, friends), as well as in other social relations (ie, within the mesosystem, exosystem, and macrosystem).

Research on the influence of cultural contexts on development most frequently emphasizes two basic dimensions of culture: collectivism versus individualism (or dependence versus independence). ${ }^{7-12}$ In accordance with this dichotomy found across different cultures, it is important to discuss the basic social needs that a person satisfies through the interactions with his or her social environment. In individualist-oriented cultures, there is an emphasis on independence and personal freedom, and the fundamental goal is to foster healthy self-esteem, personal achievement, and creativity. ${ }^{13-17}$ In these surroundings, young people are encouraged to be self-reliant and independent from their family and peers. An individualist culture is characterized by its people's tendencies to develop poor emotional relationships with their surroundings, as well as by loose social relations. ${ }^{18}$ In contrast, different goals and priorities are set for individuals in collectivist cultures. In collectivist cultures, togetherness is encouraged and it prevails over individuality across all contexts. Moreover, personal needs fall within a hierarchy of needs, and are often below the needs of the community and the peer or family groups to which the individual belongs.

What is significant for development and developmental psychology relates to the consequences which these differences in cultures cause at the individual level. What are significant for developmental psychology and for the development of an individual are the consequences that are associated with these different cultural expectations. Triandis et $\mathrm{al}^{7}$ and Triandis ${ }^{8,9}$ call these differences allocentrism versus idiocentrism. Allocentrism includes more social support, and it implies that the individual is surrounded by a strong social network. Such a relationship with the environment results in greater levels of satisfaction and a higher quality of social relations. Allocentrism, as an "otherfocused orientation" results in a lower level of alienation and loneliness. Idiocentrism, as a "self-focused orientation" is positively correlated with academic success and loneliness. ${ }^{7}$ In other words, the authors assume that the criteria for distinguishing allocentrism from idiocentrism are the strength of social support, which is manifested in the quantity of and an individual's satisfaction with his or her social network, as well as the individual's perception of loneliness.

Parents' educational aims and styles also vary according to the cultural environment. ${ }^{10}$ Modern cultures are becoming increasingly similar to each other in their pursuit of money, the production of goods, and information exchange; in this light, money or other goods are often used to encourage educational achievement. In environments in which individuals prioritize themselves and their own achievements, social relations at the asymmetrical (eg, parent-child) and symmetrical (eg, friend-friend) levels differ from social relations in environments in which individuals are oriented to others. In collectivist cultures, social relations at the asymmetrical level are very important (eg, parent-child), and there is a hierarchical relationship in which a parent cares for the child and tries to participate in almost all spheres of the child's life. In individualist cultures, greater importance is placed on symmetrical relationships (eg, friend-friend). The strength of the social network is weaker, individuals are not tightly linked to others in their immediate surroundings, and they do not tend to develop attachments to significant others. Individual needs and independence are emphasized, and, as a result, individuals from individualist cultures can 
leave one group and join another with great ease. Therefore, it can be concluded that in collectivist cultures social support is stronger than in individualist cultures, whereby social support is significantly weaker. Furthermore, in collectivist cultures, the individual wants to belong to and enjoys being part of a group, while the individual in an individualist cultural does not. ${ }^{7,12,18}$

There are numerous studies that have investigated the influence of culture on development, ${ }^{15,19-23}$ and the most numerous are those that examine the differences between Eastern cultures as being representative of collectivist cultures, and Western cultures, which represent individualist cultures. However, it should be said that the impact of globalization processes as well as the development of technology have changed cultural boundaries between the East and West. Therefore, today, we can ask the question about which cultures fall at the extreme ends of the continuum of cultural dimensions. In addition, it should be pointed out that research on the developmental impacts of individualist versus collectivist cultures in the Balkan region is extremely rare (at least to our knowledge). One of the special features of this region is that its postwar period (after 1996) was followed by a relatively stable period characterized by a socialist economy, as well as strong social relations. ${ }^{24}$ The subsequent transition from socialism to capitalism required adjustments of both society as a whole and of each individual.

The period of "transitional contradictions" 25 was marked by a sudden abandonment of the old system and the establishment of a system with new economic, political, and ideological characteristics. ${ }^{26}$ Social changes that occurred at different levels of intensity and speed emerged in the states of former Yugoslavia, and within the context of different religious affiliations, which must have also affected the region's cultural landscape, as well as each individual's development. ${ }^{27}$ Thus one of the most comprehensive studies that examined the dimensions of individualistic versus collectivist cultures across 50 countries was conducted by Hofstede. ${ }^{28}$ The findings suggested that the countries of former Yugoslavia are marked by collectivism; however, as Katunaric ${ }^{29}$ points out, what should be taken into account when interpreting these findings are the time when the study was conducted as well as the characteristics of the sample on which it was conducted (ie, workers in the automobile industry in Kragujevac in central Serbia). The most recent research in this area points to an increasingly dominant individualist orientation in Croatia, especially among young people. $^{30,31}$ In this light, this study attempts to investigate some of the characteristics of adolescents across three different countries: Croatia, Bosnia and Herzegovina, and Macedonia.

The main aim of this study was to determine whether there were differences in the peer and parent social interactions in adolescents from these three different countries and to detect potential clusters of variables that most accurately identify adolescents from different cultures. The basic assumption of this research is that there are differences in the social interactions of young people in these countries, which arise from the geographic, economic, and religious contexts and experiences that adolescents have lived through during the war and postwar periods. For instance, it is assumed that the extent of the destruction in a given country (whether it be economic destruction, loss of life, different levels of unemployment and migration, the marginalization of groups of people, and so on) affect an individual's development. In other words, the strength of a given social network may differ across the three investigated countries due to their historical, cultural, geographic, and economic diversity, which may be especially related to the postwar social and political events in these countries.

\section{Methods \\ Subjects}

A total of 1033 adolescents from high schools across the following three countries participated in this study: the Republic of Croatia, Bosnia and Herzegovina, and Macedonia. The sample of Croatian students consisted of 390 subjects (Zadar, mid-Dalmatia); the sample of adolescents in Bosnia and Herzegovina comprised 353 subjects (Žepče, mid-Bosnia); while the sample of Macedonian adolescents consisted of 290 individuals. In all three countries, there were equal numbers of adolescents who attended grammar school or vocational school, as well as an equal number of students from each of the four classes (two classes from each school). There were a total of 444 male and 581 female subjects (eight subjects did not state their sex).

\section{Procedures}

This study was conducted in three countries; the study was completed in the Republic of Croatia and in Bosnia and Herzegovina during April 2007, and in Macedonia during October of the same year, during a 2-week period. Two grammar schools and two vocational schools from the abovementioned states were included in the study. In addition, a number of scales were administered across each group. This process lasted less than 1 hour and was done during regular class time. 


\section{Measures}

\section{The Family Satisfaction Scale}

The Family Satisfaction Scale ${ }^{32}$ measures the child's feelings about his or her family as a whole. It contains eleven items, which refer to feelings of safety, happiness, and satisfaction with family life. Some of the items included in this scale are: "My family is a source of consolation and satisfaction for me," and "My family gets on my nerves."

The subjects' task was to circle on a five-point scale to what extent the content of the item was true for them; a score of 1 indicated that the item was not true at all, and 5 suggested that the item was completely true. In this study, the Cronbach's alpha reliability coefficient was 0.90 , and all items showed a high level of reliability. The average score on the scale was $\mathrm{M}=45.48$ ( $\mathrm{SD}=7.94)$. The scale had a one-dimensional structure and the percentage of the explained variance was $45 \%$. The result obtained on this scale is interpreted as the level of satisfaction with one's family and family life.

\section{Family and social loneliness scales}

The scales used for measuring the levels of loneliness within the family and in social settings are a part of the Scale of Social and Emotional Loneliness. ${ }^{33}$ The scale of loneliness in the family consisted of ten items. The original scale had one additional item ("I truly care for my family"), which was left out from further analysis due to insufficient reliability levels. The subjects' task was to assess the accuracy of each item on a five-point scale, where 1 meant that the item was not true at all and 5 meant that it was completely true. The scale measures different types of family relations and one's overall level of satisfaction with these relationships. For instance, this scale assesses whether one's family satisfies the individual's need of family belonging, whether there is a sense of understanding from family members, whether family members offer support, and if members of a family share positive emotions. Some of the items on this scale include: "No one in my family cares about me," and "I feel that I belong to my family." The reliability level of this scale was satisfactory (Cronbach's alpha of 0.87 ) and it explains $46.70 \%$ of common variance. The average mean on the scale for the entire sample is $\mathrm{M}=17.37$ ( $\mathrm{SD}=8.43$ ).

The social loneliness scale consists of 13 items and measures if individuals find that their friendships satisfy their needs for understanding, support, and intimacy. Items characteristic of this scale are: "My friends understand my needs and way of thinking," and "I am not satisfied with the friends I have." The internal reliability of this scale is satisfactory, with a Cronbach's alpha of 0.86 , which explains $38 \%$ of common variance. The mean values of the whole sample are $\mathrm{M}=25.32(\mathrm{SD}=8.43)$. Both scales have a onedimensional structure.

\section{The scales of parent and friend influence}

In order to more extensively research this topic, we constructed an instrument that measures the extent to which adolescents are influenced by their parents or friends in decision-making across different spheres of life, such as with clothing, entertainment, school, and sexuality choices, as well as with moral dilemmas and so on. On the scales of parent and friend influence, ${ }^{34}$ each subject simultaneously assessed the influence that parents and peers had on his or her particular behaviors. The scale consisted of 13 items which examined parents' levels of influence, and the same 13 items were also used to investigate whether peers influenced participants' behaviors. This scale includes items such as: "The way I dress;" "My school achievement;" "The relationship with my boyfriend/girlfriend;" and "My attitude towards the world, in general." The subjects circled the extent to which parents and friends influenced them in decision-making on a five-point scale, where a score of 1 indicated that there was no influence at all, and 5 meant that there was a high level of influence.

Exploratory factor analysis was conducted for each scale (parent influence, friend influence). Each scale showed a single-factor structure. For the Scale of Parent Influence, this factor explained $29 \%$ of the total variance, and for the Scale of Friend Influence it explained $31 \%$ of the total variance.

Analysis of the internal consistency of both of these onedimensional scales implied that there was a satisfactory level of reliability for the scales of parent and friend influence. The Cronbach's alpha reliability coefficient for the Scale of Parent Influence was 0.84, while the Scale of Friend Influence had a reliability coefficient of 0.83 . The value on The Parent Influence Scale is interpreted as the strength of the parents' level of influence on decision making (the mean value on this scale was $\mathrm{M}=38.60, \mathrm{SD}=9.61$ ), while the mean on the Friend Influence Scale was interpreted as the friends' level of influence on decision making (the mean value on this scale was $\mathrm{M}=35.03, \mathrm{SD}=10.23$ ).

\section{The Friendship Quality Scale}

The Friendship Quality Scale ${ }^{35}$ consists of 30 items that evaluate friendships and their degree of emotional support, conflict resolution, as well as mutual helping and sharing. The subjects' task was to assess the accuracy of each item on a 
five-point scale, where 1 meant that the item was not true at all and 5 meant that it was completely true. The Cronbach's alpha reliability coefficient for this scale was 0.94 . The scale showed a one-factor structure and explained $38.77 \%$ of the common variance, while the mean value of the entire sample was $\mathrm{M}=120.04(\mathrm{SD}=19.32)$.

The result on this scale was interpreted as a level of friendship quality. Some of the items included on this scale were: "We always lend things to each other," "My friend defends me if someone gossips about me," and "We confide in each other."

\section{The Scale of Aggressive and Prosocial Behavior}

The Scale of Aggressive and Prosocial Behavior ${ }^{36}$ consists of 20 items, ten of which refer to aggressive behavior, while the other ten refer to prosocial behavior. The original items, which were used to measure patterns of behavior in preschool children in previous research, were adapted for use in adolescents. ${ }^{37}$ Each subject's task was to assess the accuracy of each item on a five-point scale, where 1 meant that the item was not true at all and 5 meant that it was completely true. The internal reliability of these scales was satisfactory; for the Scale of Aggressive Behavior, the Cronbach's alpha reliability coefficient was 0.76 , while it was 0.79 for the Scale of Prosocial Behavior. The means were as follows: the Scale of Aggressive Behavior $(\mathrm{M}=23.73, \mathrm{SD}=6.36)$; the Scale of Prosocial Behavior $(M=38.02, S D=5.93)$. The results on the Scale of Aggressive Behavior explain 27\% of common variance, while those on the Scale of Prosocial Behavior account for 29\%. Items from the Scale of Aggressive Behavior included: "I fight and yell at others," and "When I am angry I hurt other people's feelings." Items on the Scale of Prosocial Behavior included: "I sympathize with others when they are punished," and "I love sharing things and ideas with other people."

\section{The Self-Esteem Scale}

This scale was constructed in accordance with Rosenberg's Self-Esteem Scale, ${ }^{38}$ and consisted of 12 items that included items such as: "I have many virtues," and "I am satisfied with myself." The subject's task was to assess the accuracy of each item on a five-point scale, where 1 meant that the item was not true at all, and 5 meant that it was completely true. The reliability results obtained on our sample $(n=1033)$ indicated satisfactory internal reliability (Cronbach's alpha of 0.84 ). The average value on this scale was $\mathrm{M}=47.43$ $(\mathrm{SD}=7.85)$. This Self-Esteem Scale has a one-dimensional structure, and the obtained values on the scale explain $33 \%$ of common variance.

Questionnaires used in Bosnia and Herzegovina were translated into the Croatian language (Croatian is one of the official languages in this region). In Macedonia, a professor of the Croatian and Macedonian languages translated the scales from Croatian to Macedonian. For this reason, it was not necessary to translate these instruments into English.

\section{Results and discussion}

Through discriminant analysis, an attempt was made to determine whether it was possible to discriminate between three groups of adolescents from the three different geographic regions. In addition, we wished to recognize some of the characteristics from the individuals' cultural environments by detecting potential clusters of predictors, which may have been fundamental to the psychological aspects of their respective cultures. Discriminant analysis showed that all the potential predictor variables may play a significant role in predicting whether individuals belong to different cultural environments (Tables 1 and 2).

After testing the significance levels of the differences noted in the measured variables using analysis of variance (Table 1) and the Scheffe test (Tables S1-S9), the following

Table I Descriptive statistics for the examined variables (samples from Croatia, BIH, and Macedonia)

\begin{tabular}{|c|c|c|c|c|c|c|c|c|}
\hline & \multicolumn{2}{|c|}{ Croatia } & \multicolumn{2}{|l|}{ BIH } & \multicolumn{4}{|c|}{ Macedonia } \\
\hline & $\mathbf{M}$ & SD & $\mathbf{M}$ & SD & $\mathbf{M}$ & SD & $\boldsymbol{F}$ & $\boldsymbol{P}$ \\
\hline Family satisfaction & 45.072 & 7.419 & 46.819 & 7.438 & 43.539 & 8.794 & 14.20 & 0.00 \\
\hline Loneliness in the family & 16.205 & 6.670 & 16.933 & 6.394 & 19.473 & 8.666 & 18.12 & 0.00 \\
\hline Social loneliness & 23.306 & 8.313 & $24.85 I$ & 8.183 & 28.626 & 7.902 & 36.30 & 0.00 \\
\hline Prosocial behavior & 38.553 & 5.487 & 38.608 & 5.870 & 36.591 & 6.357 & 11.96 & 0.00 \\
\hline Aggressive behavior & 23.432 & 6.139 & 22.190 & 5.963 & 25.999 & 6.489 & 30.94 & 0.00 \\
\hline Parent influence & 35.542 & 8.082 & 40.622 & 9.672 & 40.244 & 10.389 & 33.76 & 0.00 \\
\hline Friend influence & 33.401 & 9.117 & 35.064 & 9.384 & 37.183 & 12.103 & II.57 & 0.00 \\
\hline Friendship quality & II8.|I & 20.709 & 121.05 & 18.179 & 121.40 & 18.573 & 3.15 & 0.04 \\
\hline Self-esteem & 48.296 & 7.693 & 46.690 & 7.592 & 47.176 & 8.285 & 4.11 & 0.02 \\
\hline
\end{tabular}

Abbreviation: $\mathrm{BIH}$, Bosnia and Herzegovina. 
Table 2 Discriminant function analysis summary, including different social variables and samples from Croatia, Bosnia and Herzegovina, and Macedonia

\begin{tabular}{llll}
\hline & Wilks' lambda & F-to-remove & P-value \\
\hline Family satisfaction & 0.768847 & 9.55046 & 0.000078 \\
Loneliness in the family & 0.762232 & 5.07156 & $0.00643 \mathrm{I}$ \\
Social loneliness & 0.806967 & 35.35957 & 0.000000 \\
Prosocial behavior & $0.76395 \mathrm{I}$ & 6.23554 & 0.002034 \\
Aggressive behavior & 0.775428 & 14.00598 & $0.00000 \mathrm{I}$ \\
Parent influence & 0.789467 & 23.51106 & 0.000000 \\
Friend influence & 0.760795 & 4.09910 & $0.01686 \mathrm{I}$ \\
Friendship quality & 0.799303 & 30.17112 & 0.000000 \\
Self-esteem & 0.771850 & $1 \mathrm{I} .58390$ & $0.00001 \mathrm{I}$ \\
\hline
\end{tabular}

Note: Wilks' lambda $=0.75474 ; F(18.044)=17.155, P<0.0000$.

conclusions could be made: adolescents from Macedonia assessed the quality of their family interactions significantly lower than adolescents from either Croatia or Bosnia and Herzegovina. In addition, adolescents from Croatia rated their perceived loneliness, as well as the level of influence from their family and friends, higher than did adolescents from Croatia and Bosnia and Herzegovina. Croatian adolescents also exhibited significantly lower prosocial behaviors and higher aggressive behaviors than the other two groups of adolescents. Adolescents from Macedonia were the loneliest in social relationships, while Croatian adolescents were least likely to feel lonely. In addition, adolescents from Croatia indicated that the level of parental influence in decisionmaking across various spheres of their lives was lower than that of adolescents from Bosnia and Herzegovina and Macedonia. Croatian adolescents also demonstrated that they had higher self-esteem than adolescents from Bosnia and Herzegovina. Lastly, post hoc analysis showed that the differences in adolescents' assessments of the quality of their friendships were minimal.

It appears that social interactions and their correlation with variables such as loneliness and self-esteem differed across the three groups of adolescents. In fact, it is to be expected that loneliness in the family as well as in other social relationships is negatively correlated with the reported quality of family and peer interactions; this assumption was partly validated among Macedonian adolescents. However, in adolescents from Croatia, lower parent and peer influence was correlated with lower loneliness and higher self-esteem ratings. In adolescents
Table 3 Classification functions (including different social variables and samples from Croatia, $\mathrm{BIH}$, and Macedonia)

\begin{tabular}{llll}
\hline & BIH & Croatia & Macedonia \\
\hline Family satisfaction & 1.734 & 1.676 & 1.676 \\
Loneliness in the family & 1.756 & 1.701 & 1.721 \\
Social loneliness & 1.328 & 1.290 & 1.410 \\
Prosocial behavior & 1.105 & 1.120 & 1.060 \\
Aggressive behavior & 0.804 & 0.838 & 0.881 \\
Parent influence & 0.316 & 0.250 & 0.306 \\
Friend influence & 0.136 & 0.156 & 0.164 \\
Friendship quality & 0.439 & 0.422 & 0.466 \\
Self-esteem & 0.879 & 0.906 & 0.940 \\
Constant & -159.17 & -153.33 & -165.18 \\
Percent of correct classification & $47.31 \%$ & $67.69 \%$ & $48.96 \%$ \\
\hline
\end{tabular}

Abbreviation: $\mathrm{BIH}$, Bosnia and Herzegovina.

from Bosnia and Herzegovina, a higher quality of family interactions and parent influence was highly correlated with loneliness and lower self-esteem. In other words, in order to raise one's self-esteem, there should be less influence from an individual's immediate surroundings. Conversely, it can also be argued that an individualistic measure of self-esteem (like the Rosenberg Self-Esteem Scale) is not entirely appropriate for use in collectivistic cultures.

When looking at the classification functions of all predictor variables among the total sample of subjects who participated in the investigation, the accuracy of prediction of belonging to different cultural environments was $55.46 \%$. Moreover, it was discovered that these variables were better able to predict whether a subject was from Croatia, as opposed to when they were from the other two countries (Table 3).

Further canonical analysis revealed two significant canonical roots (Table 4). The factor structure matrix of the predictor variables is shown in Table 5. The analysis indicated that there were two significant discriminant functions across which adolescents from the three different cultures could be distinguished. The first function adequately discriminated between the subjects across all three cultural environments, and was primarily associated with the variables related to social and family loneliness, as well as friend influence. The greatest differences noted with regard to the first function were between adolescents from Croatia and Macedonia, while adolescents from Bosnia and Herzegovina were positioned somewhere in between (Table 6; Figure 1).

Table 4 Chi-squared tests with successive roots removed

\begin{tabular}{lllllll}
\hline & Eigen-value & Canonical $\boldsymbol{R}$ & Wilks' lambda & Chi-squared & df & $P$-level \\
\hline Root 0 & 0.215778 & 0.421286 & 0.754741 & 288.6964 & 18 & 0.000000 \\
Root I & 0.089802 & 0.287058 & 0.917598 & 88.2319 & 8 & 0.000000 \\
\hline
\end{tabular}


Table 5 Factor structure matrix - canonical roots (pooled within-group correlations)

\begin{tabular}{lll}
\hline & Root I & Root 2 \\
\hline Family interaction quality & 0.259421 & 0.381265 \\
Loneliness in the family & -0.398968 & -0.096896 \\
Social loneliness & -0.569764 & -0.069827 \\
Prosocial behavior & 0.300626 & 0.203820 \\
Aggressive behavior & -0.389270 & -0.552235 \\
Parent influence & -0.407169 & 0.575796 \\
Friend influence & -0.321201 & 0.047936 \\
Friendship quality & -0.40213 & 0.144562 \\
Self-esteem & 0.111414 & -0.242978 \\
\hline
\end{tabular}

The main characteristics of the first function included lower levels of loneliness in the family, lower levels of loneliness in social relationships, and lower levels of parent and friend influence in decision making. On the other hand, the most notable finding for adolescents from Macedonia was the high level of social loneliness and loneliness in the family. According to Triandis et al, ${ }^{7}$ the strength of social support - which should be associated with both parent and friend influence - is negatively correlated with the perception of loneliness. It is important to note that the parent and friend influence scale used in this study is actually a scale of "influence intensity," and it is therefore not possible to say whether participants regarded higher levels of influence in a positive (ie, motivating, encouraging, or constructive) or negative light (ie, a parent or friend exerting too much control, austerity, or rigidity). In this context, the amount of social support is related to a "positive" perception of parental influence, while the "negative" influence may be interpreted completely differently in the form of coercion or pressure. Therefore, it is not quite unexpected that the results showed a relationship in which lower loneliness in the family and in social interactions were related to lower parental and peer influence. It is also important to emphasize that the subjects in this study were adolescents - a group of young people whose searches for individual identity often manifest in resistance to others, especially parents. ${ }^{39}$

The second function suggests that adolescents from Bosnia and Herzegovina can be differentiated from adolescents from the other two cultural environments, and this factor is primarily related to a better quality of family interaction, lower aggression, greater parent influence, and lower self-esteem. This function appears to suggest that Bosnia and Herzegovina (the central part of the country is mostly populated by Muslims and Croats) may share the same features of a collectivist culture when compared to the other two regions, which did not exhibit significant differences. In this context, it is interesting to emphasize that lower self-esteem appears to be characteristic of adolescents from more collectivistic environments. It is also interesting to point out that lower self-esteem is associated with greater parental influence, but not friend influence. However, it should be noted that there are no unambiguous or clear connections between the sociological and psychological dimensions of any given culture.

$\mathrm{Ghosh}^{40}$ examined different groups of subjects in India, and it was revealed that there were different proportions of collectivism and individualism within the country. The groups differed according to sex, age, employment status, socioeconomic status, and the type of family to which they belonged. According to the results obtained in this study, it could be concluded that the measures that were applied here may also be able to distinguish between the three groups of adolescents from these three cultural environments.

In sum, it should be emphasized that cross-cultural research in transitional countries may yield very interesting findings for scientists of different vocations, and the results of these studies could have very useful applications in many social and political domains in a given region. Future research in this field should include a larger number of psychological and sociological variables (such as the level of aspiration, competitiveness, and so on) to determine whether certain groups of individuals exhibit other characteristics that vary in accordance with their cultural environments.

\section{Study limitations}

It is worth mentioning some specific limitations of the present study. First, it was impossible to include all of factors that might assess adolescents' social interactions with parents and peers. Future studies may need to evaluate specific factors such as interactions with mothers and fathers, group status within one's peer group, and other such variables that might influence

Table 6 Squared mahalanobis distances and means of canonical variables

\begin{tabular}{|c|c|c|c|c|c|}
\hline & BIH & Croatia & Macedonia & Root I & Root 2 \\
\hline $\mathrm{BIH}$ & 0.000000 & 0.598594 & 0.900333 & 0.051852 & 0.413966 \\
\hline Croatia & 0.598594 & 0.000000 & 1.331201 & 0.464467 & -0.240513 \\
\hline Macedonia & 0.900333 & 1.331201 & 0.000000 & -0.687745 & -0.180449 \\
\hline
\end{tabular}

Abbreviation: $\mathrm{BIH}$, Bosnia and Herzegovina. 


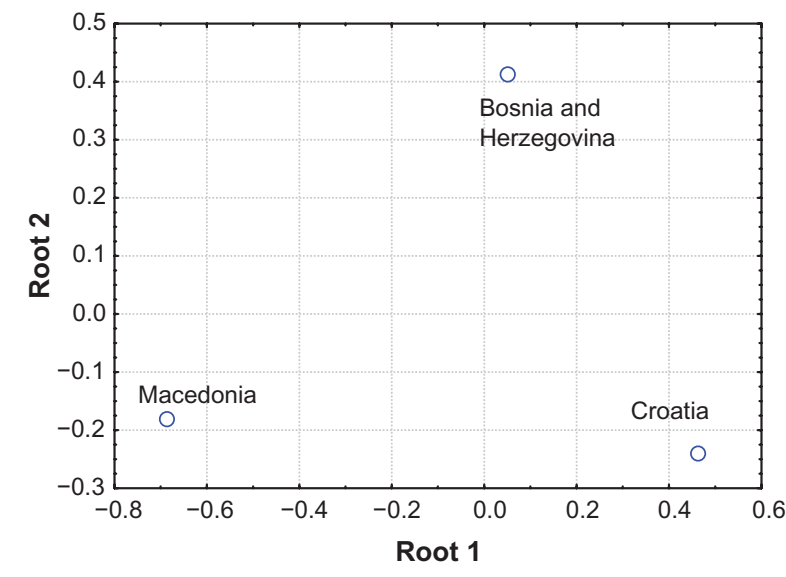

Figure I Graphic presentation of canonical variable means.

aggressive and prosocial behavior, as well as self-esteem. Second, our study used self-report measures to explore all of the variables. Individuals may evaluate themselves differently from others based on how they actually feel about themselves and others. Thus, future studies should use different methods of evaluating self-esteem, as well as aggressive and prosocial behavior. Third, we did not control for cultural variables such as specific values and norms in order to understand how cultural orientation relates to behavior and self-esteem, and this may have affected the results of this study. Despite these limitations, this study is one of the few that has examined how different cultures and their specific features and values are related to social interactions among adolescents.

\section{Disclosure}

The authors report no conflicts of interest in this work.

\section{References}

1. Tietjen A. Supportive interaction in cultural context. In Nestmann F, Hurrelman K, editors. Social networks and social support in childhood and adolescence. Berlin, Walter de Gruyter, 1994:395-409.

2. Hartup WW. The social worlds of childhood. American Psychologist. 1979;34/10:944-950.

3. Youniss J. Parent and peer relations in the emergence of cultural competence. In: McGork H, editor. Childhood Social Development: Contemporary Perspective. Hove, England: Erlbarm Associates; 1992:131-147.

4. Bowlby J. Attachment and Loss-Separation, Anxiety and Anger. Tavistock: Basic Books A Member of the Perseus Books Group; 1973.

5. Chen X, French DC, Schneider BH. Culture and peer relationships. In: Chen X, French DC, Schneider BH, editors. Peer Relationships in Cultural Context: Cambridge Studies in Social and Emotional Development. New York: Cambridge University Press; 2006:3-20.

6. Bronfenbrenner U. The Ecology of Human Development. Cambridge, MA: Harvard University Press; 1979.

7. Triandis HC, Bontempo R, Villareal MJ, Asai M, Lucca N. Individualism and collectivism: cross-cultural perspectives on selfingroup relationships. J Pers Soc Psychol. 1988;54(2):323-338.
8. Triandis HC. Cross-cultural studies of individualism and collectivism. In: Berman JJ, editor. Nebraska Symposium on Motivation, 1989: Cross-Cultural Perspectives. Lincoln: University of Nebraska Press; 1990:41-133.

9. Triandis HC. Collectivism and individualism as cultural syndromes. Cross-Cultural Research. 1993;27(3-4):155-180.

10. Kağitçibasi Ç. Family, Self, and Human Development Across Cultures: Theory and Applications. New York: Psychology Press; 2009.

11. Allik J, Realo A. Individualism-collectivism and social capital. J Cross Cult Psychol. 2004;35(1):29-49.

12. Oyserman D, Coon HM, Kemmelmeier M. Rethinking individualism and collectivism: evaluation of theoretical assumptions and meta-analyses. Psychol Bull. 2002;128(1):3-72.

13. Brown JD, Cai H, Oakes MA, Deng C. Cultural similarities in self-esteem functioning. J Cross Cult Psychol. 2009;40(1): $140-157$.

14. Zha P, Walczyk JJ, Griffith-Ross DA, Tobacyk JJ, Walczyk DF. The impact of culture and individualism-collectivism on the creative potential and achievement of American and Chinese adults. Creativity Research Journal. 2006;18(3):355-366.

15. Rogoff B. The Cultural Nature of Human Development. Oxford: Oxford University Press; 2003.

16. Diener E, Diener M. Cross-cultural correlates of life satisfaction and self-esteem In: Diener E, editor. Culture and Well-Being: The Collected Works of Ed Diener. New York: Springer 2009:71-91.

17. Tsai JL, Ying YW, Lee PA. Cultural predictors of self-esteem: a study of Chinese American female and male young adults. Cultur Divers Ethnic Minor Psychol. 2001;7(3):284-297.

18. Triandis HC. Individualism Collectivism. Boulder, CO: Westview Press; 1995.

19. Valsiner J, editor. Child Development in Cultural Context. Toronto: Hogrefe and Huber Publishers; 1989.

20. Peterson GW, Bush KF, Wilson SM, Hennon CB. Family Relationship Predictors of Parent-Adolescent Conflict: Cross-Cultural Similarities and Differences. International Family Strengths Consortium, Cuernavaca, Mexico; 2005. Available from: http://www.ciesas.edu. $\mathrm{mx} /$ proyectos/mifs2005/papers/04/peterson_bush_wilson_hennon.pdf. Accessed July 3, 2008.

21. Crockett LJ. Cultural, historical, and subcultural context of adolescence: implications for health and development. In: Schulenberg J, Maggs JL, Hurrelmann K, editors. Health Risks and Developmental Transitions During Adolescence. New York: Cambridge University Press; 1997:23-53.

22. Rubin KH. Social and emotional development from a cultural perspective. Dev Psychol. 1998;34(4):611-615.

23. Lee K, Johnson AS. Child development in cultural contexts: implications of cultural psychology for early childhood teacher education. Early Childhood Education Journal. 2007;35(3):233-243.

24. Lacković-Grgin K. Usamljenost: Fenomenologija, Teorije i Istraživanja [Loneliness: Phenomenology, Theory, and Research]. Jastrebarsko: Naklada Slap; 2008. Croatian.

25. Črpić G, Zrinščak S. Dinamičnost u stabilnosti: Religioznost u Hrvatskoj 1999 i 2008. [Dynamism in stability: religiosity in Croatia in 1999 and 2008]. Društvena Istraživanja. 2010;19(1-2):3-27. Croatian.

26. Jeknić R. Individualističke i kolektivističke kulture u kontekstu globalizacije: Hofstedeov model i njegova kritika [Individualist and collectivist cultures in the context of globalization: Hofstedeov model and its critics]. Revija za Sociologiju. 2006;37(3-4):205-225.

27. Newhouse L. Slavic families. In: McGoldrick M, Giordano J, Garcia-Preto N, editors. Ethnicity and Family Therapy. New York: The Guilford Press; 2005:711-724.

28. Hofstede G. National cultures in four dimensions. A research-based theory of cultural differences among nations. International Studies of Management and Organization. 1983:13(1/2):46-74.

29. Katunarić V. Od distance prema srodnosti: model "'nacionalne kulture" Geerta Hofstedea [From distance to similarities: Geert Hofstede's "national culture" model]. Pedagogijska Istraživanja. 2004:1(1):25-39. Croatian. 
30. Ilišin V, Radin F. Mladi uoči trećeg milenija [Young Eve of the Third Millennium] Zagreb: Institut za društvena istraživanja: Državni zavod za zaštitu obitelji, materinstva i mladeži; 2002. Croatian.

31. Županov J. The social legacy of communism. Društvena Istraživanja. 1996:5(2)425-455.

32. Vulić-Prtorić A. Skala kvalitete obiteljskih interakcija-KOBI [The scale quality of family interaction - KOBI]. In: Proroković A, Lacković-Grgin K, Ćubel Adorić V, Penezić Z, editors. Zbirka Psihologijskih Skala $i$ Upitnika Svezak 2. [Collection of Scales and Psychological Questionnaires Volume 2]. Zadar: Sveućilište u Zadru; 2004:24-32. Croatian.

33. Ćubela-Adorić V, Nekić M. Skala Socijalne i emocionalne usamljenosti [The scale of social and emotional loneliness]. In: Proroković A, Lacković-Grgin K, ćubel-Adorić V, Penezić Z, editors. Zbirka Psihologijskih Skala i Upitnika. Svezak 2. [Collection of Scales and Psychological Questionnaires Volume 2]. Zadar: Sveućilište u Zadru; 2004:52-61. Croatian.

34. Klarin M, Proroković A, Šimić Šašić S. Obiteljski i vršnjaćki doprinos donošenju odluka iz razlićitih sfera života kod adolescenata Kroskulturalna perspektiva [Family and peer contribution to decision making in different aspects of life for adolescents - cross-cultural perspective]. Društvena Istraživanja. 2010;3(107):547-559. Croatian.

35. Klarin M. Doprinos vršnjaćkih odnosa percepciji socijalne podrške kod djece školske dobi [The contribution of peer relations perception of social support for children of school age]. Zborniku Radova Sveućilišta u Zadru. 2005;5:69-85. Croatian.
36. Žužul M, Keresteš G, Vlahović-Štetić V. Skala za procjenu djećjeg agresivnog i prosocijalnog ponašanja [Scale for assessment of children's aggressive and prosocial behavior]. Primijenjena Psihologija. 1990;11:77-86. Croatian.

37. Klarin M. Odnosi u Obitelji i s Vršnjacima kao Prediktori Razlićitih Aspekata Prilagodbe $u$ Školi [Relations in the Family and Peers as Predictors of Different Aspects of Adjustment in School] [doctoral dissertation]. Zagreb: University of Zagreb. 2000; Croatian.

38. Vizek-Vidović V, Kuterovac-JagodićG. Self-Worth Scale for ChildrenEvaluation Report. School-Based Health and Peace Initiative. Zagreb: Unicef and Care; 1996.

39. Kroger J. Identity Development. London: Sage Publications, Inc; 2000.

40. Ghosh A. Individualist and collectivist orientations across occupational groups. In: Setiadi BN, Supratiknya A, Lonner WJ, Poortinga YH, editors. Ongoing Themes in Psychology and Culture. Melbourne, FL: International Association for Cross-Cultural Psychology; 2004. Available from: http://ebooks.iaccp.org/ongoing_themes/chapters/ghosh/ ghosh.php?file=ghosh\&output=scree. Accessed October 11, 2012 


\section{Supplementary materials}

Table SI Post hoc analysis for quality of family interaction

\begin{tabular}{llll}
\hline State & Croatia & $\begin{array}{l}\text { Bosnia and } \\
\text { Herzegovina }\end{array}$ & Macedonia \\
\hline Croatia & & \\
Bosna and Herzegovina & 0.15 & \\
Macedonia & 0.00 & 0.00 \\
\hline
\end{tabular}

Table S2 Post hoc analysis for loneliness in the family

\begin{tabular}{llll}
\hline State & Croatia & $\begin{array}{l}\text { Bosnia and } \\
\text { Herzegovina }\end{array}$ & Macedonia \\
\hline Croatia & & \\
Bosna and Herzegovina & 0.39 & \\
Macedonia & 0.00 & 0.00 \\
\hline
\end{tabular}

Table S3 Post hoc analysis for social loneliness

\begin{tabular}{llll}
\hline State & Croatia & $\begin{array}{l}\text { Bosnia and } \\
\text { Herzegovina }\end{array}$ & Macedonia \\
\hline Croatia & & \\
Bosna and Herzegovina & 0.04 & \\
Macedonia & 0.00 & 0.00 \\
\hline
\end{tabular}

Table S4 Post hoc analysis for prosocial behavior

\begin{tabular}{llll}
\hline State & Croatia & $\begin{array}{l}\text { Bosnia and } \\
\text { Herzegovina }\end{array}$ & Macedonia \\
\hline Croatia & & \\
Bosna and Herzegovina & 0.99 & \\
Macedonia & 0.00 & 0.00 \\
\hline
\end{tabular}

Table S5 Post hoc analysis for aggressive behavior

\begin{tabular}{llll}
\hline State & Croatia & $\begin{array}{l}\text { Bosnia and } \\
\text { Herzegovina }\end{array}$ & Macedonia \\
\hline Croatia & & \\
Bosna and Herzegovina & 0.02 & \\
Macedonia & 0.00 & 0.00 \\
\hline
\end{tabular}

Psychology Research and Behavior Management

\section{Publish your work in this journal}

Psychology Research and Behavior Management is an international, peerreviewed, open access journal focusing on the science of psychology and its application in behavior management to develop improved outcomes in the clinical, educational, sports and business arenas. Specific topics covered include: Neuroscience, memory \& decision making; Behavior
Table S6 Post hoc analysis for parent influence

\begin{tabular}{llll}
\hline State & Croatia & $\begin{array}{l}\text { Bosnia and } \\
\text { Herzegovina }\end{array}$ & Macedonia \\
\hline Croatia & & \\
Bosna and Herzegovina & 0.00 & \\
Macedonia & 0.00 & 0.87 \\
\hline
\end{tabular}

Table S7 Post hoc analysis for friend influence

\begin{tabular}{llll}
\hline State & Croatia & $\begin{array}{l}\text { Bosnia and } \\
\text { Herzegovina }\end{array}$ & Macedonia \\
\hline Croatia & & \\
Bosna and Herzegovina & 0.08 & \\
Macedonia & 0.00 & 0.03 \\
\hline
\end{tabular}

Table S8 Post hoc analysis for friendship quality

\begin{tabular}{llll}
\hline State & Croatia & $\begin{array}{l}\text { Bosnia and } \\
\text { Herzegovina }\end{array}$ & Macedonia \\
\hline Croatia & & \\
Bosna and Herzegovina & 0.11 & \\
Macedonia & 0.09 & 0.98 \\
\hline
\end{tabular}

Table S9 Post hoc analysis for self-esteem

\begin{tabular}{llll}
\hline State & Croatia & $\begin{array}{l}\text { Bosnia and } \\
\text { Herzegovina }\end{array}$ & Macedonia \\
\hline Croatia & & \\
Bosna and Herzegovina & 0.02 & \\
Macedonia & 0.18 & 0.74 \\
\hline
\end{tabular}

\footnotetext{
Submit your manuscript here: http://www.dovepress.com/psychology-research-and-behavior-management-journal
}

\section{Dovepress}

modification \& management; Clinical applications; Business \& sports performance management; Social and developmental studies; Animal studies. The manuscript management system is completely online and includes a quick and fair peer-review system. Visit http://www.dovepress. com/testimonials.php to read real quotes from published authors. 